\title{
Appraisal for the environment, weathering and provenance of Upper Cretaceous-Lower Tertiary shales, Western Desert, Egypt
}

\author{
Abdelaziz EL SHINAWI', Fatma RAMADAN ${ }^{2}$ and Martina ZELENAKOVA ${ }^{3 *}$
}

\author{
Authors' affiliations and addresses: \\ ${ }^{1}$ The Environmental Geophysics Lab (ZEGL), \\ Department of Geology, Faculty of Science, \\ Zagazig University, Egypt \\ e-mail: geoabdelaziz@yahoo.com \\ ${ }^{2}$ Department of Geology, Faculty of Science, \\ Zagazig University, Egypt \\ e-mail: fs_ramadan@hotmail.com \\ ${ }^{3}$ Institute of Environmental Engineering, Faculty \\ of Civil Engineering, Technical, University of \\ Kosice, 04200 Kosice, Slovakia \\ e-mail: martina.zelenakova@tuke.sk \\ *Correspondence: \\ Martina Zelenakova, Institute of Environmental \\ Engineering, Faculty of Civil Engineering, \\ Technical, University of Kosice, 04200 Kosice, \\ Slovakia \\ tel.: +421556024270 \\ e-mail: martina.zelenakova@tuke.sk
}

\section{Acknowledgement:}

We are gratefully acknowledged the anonymous reviewers for the constructive. Also, we are greatly grateful to Dr. Salah Sameih, (Egyptian Geological Survey Authority) for providing samples used in this study and the data concerned the stratigraphy of the study section.

How to cite this article:

El Shinawi, A., Ramadan, F. and Zelenakova, M. (2021). Appraisal for the environment,

weathering and provenance of Upper CretaceousLower Tertiary shales, Western Desert, Egypt. Acta Montanistica Slovaca. Volume 26 (1) 171184

DOI:

https://doi.org/10.46544/AMS.v26i1.15

\begin{abstract}
The combination of the mineralogical and geochemical composition of shales is considered a key to decipher their environment evolution, weathering, climatic conditions, and provenance. The Upper Cretaceous-Lower Tertiary succession is extensively dispersed in Egypt. The present work is devoted to studying the Dakhla shales of (Maastrichtian- Danian), Duwi (Campanian) and Quseir (pre-Campanian) formations. Chemical and mineralogical analyses were conducted by using seven representative surface sections from Dakhla Oasis. Dakhla shales are dominates by Smectite and kaolinite. The average percentages of $\mathrm{SiO}_{2}, \mathrm{Al}_{2} \mathrm{O}_{3}$, $\mathrm{CaO}, \mathrm{MgO}, \mathrm{Na}_{2} \mathrm{O}$ and $\mathrm{K}_{2} \mathrm{O}$ are subordinate values. In contrast, $\mathrm{Al}_{2} \mathrm{O}_{3}$ contents of Dakhla shale, $\mathrm{TiO}_{2}, \mathrm{P}_{2} \mathrm{O}_{5}$ and $\mathrm{Fe}_{2} \mathrm{O}_{3}$, contents are relatively higher than common shale composition. The CIA and CIW high values due to clay minerals and the absence of feldspars. This is also confirmed by the smectite domination and subordinate kaolinite in these formations. The ICV values for Dakhla and Duwi shales are 0.59 and 0.74 (ICV $<1)$. The shale is mature and deposited in a quiescent environment. Whereas the ICV for Quseir shale is 1.24 , it can be incidental that it is immature. The shale is wholly detrital and a product of moderate to intensive weathering. The provenance was constituted of granitic and basaltic source rocks, and the parent provenance is basalt. Consequently, the shale is deposited under fluvio-marine environments, and the prevailed condition was of alkaline chemical affinity probably passed through different environments varying from a fluvial, eolian and shallow marine.
\end{abstract}

\section{Keywords}

Depositional environment, clay minerals, weathering; Dakhla shale, thermal analyses. 


\section{Introduction}

Geochemical analysis of shale can introduce information on the environment, provenance, weathering conditions, and sediment recycling (Peng et al., 2014). Further studies (for example, Rowe et al., 2008; Ross and Bustin, 2009; Smaill, 2015; Jianhua Zhao et al., 2016; and Nabih and El Shinawi, 2020) show that the main factors affecting compositions of sediments are source rock, source area weathering, sorting, tectonic setting, diagenesis, and recycling. Moreover, tectonics are organised by the uplifting rate and the landforms gradient (Pandey and Parchaa 2013). As well, the geochemistry of the sediments is very significant for considering the erosional features of the basin and record the erosional and weathering process (Moufti and Németh, 2016, El Shinawi and Naymushina, 2015 and Kramarenko et al., 2016). The geochemistry of shale is a valuable tool in the study of paleoclimatic conditions of sediments (Wronkiewicz and Condie, 1987; Feng and Kerrich, 1990) and provided constraints on the continental crust evolution through time. Furthermore, a variable studies of shales elemental composition with the goal of defining the provenance of sedimentary rocks (McLennan and Taylor, 1991; and Nesbitt, 1982). The major elements are useful in understanding the rock compositions, provenance and tectonic setting of the deposited sedimentary rocks (McLennan et al. 1991). On the other hand, major element compositions are precise by weathering, lithology, and diagenesis. Consequently, clastic sediments have a vital role in identifying the composition and environment of the source rocks (Peng et al., 2018 Peng et. al., 2018 and Abdeltawab et al., 2013). The geochemistry imitates mostly the principal mineralogy of the parent rock and the overlaid belongings of pre- and post-depositional chemical weathering, well-ordered by element mobility and founding secondary phases such as clays (Philippe Négrel et al., 2021). Moreover, their mineralogical and chemical composition were influenced by factors such as weathering, source provenance, and diagenetic processes. Specifically, clay minerals provide constraints on continental weathering under different climatic conditions (Thiry, 2000; and Song et al., 2012 and Attwa, and El Shinawi, 2014). Hence, shale geochemistry is a helpful tool in studying the paleoclimatic conditions, tectonic setting, and provenance of sediments. Therefore, geochemical studies of fine sediments such as shale is the most beneficial rock attributable to their homogeneity (Christopher et al., 2017; Alqahtani and Khalil, 2019). Recent geochemical inquiries for shales are concerned with the provenance and tectonic evolution of sedimentary basins. The ratios of minor and major oxides, such as $\mathrm{Sio}_{2} / \mathrm{Al}_{2} \mathrm{O}_{3}$, high due to enriched Al-rich clay minerals relative to quartz mineral and high $\mathrm{Sio}_{2} / \mathrm{Al}_{2} \mathrm{O}_{3}$ are due to enrichment quartz. Additionally, used alkali oxides to reveal facts about the provenance of the clastic sediments. Furthermore, $\mathrm{CIA}$ and $\mathrm{Al}_{2} \mathrm{O}_{3}-\left(\mathrm{CaO}+\mathrm{Na}_{2} \mathrm{O}\right)-\mathrm{K}_{2} \mathrm{O}(\mathrm{A}-\mathrm{CN}-\mathrm{K})$ ternary plots are useful geochemical parameters for study the provenance and rocks maturity (Armstrong-Altivin et al., 2004; Lee et al., 2005; Wanas and Abdelmeguid, 2006; Campos Alveraz and Roser, 2007). However, very few studies conducted geochemical data to study the depositional environments, weathering, and provenance of deposits. Consequently, clay minerals are used as paleo-climatic indicators. Clay mineralogy delivers important information regarding the characteristics of paleoclimate, provenance, and diagenetic environments. By contrast, climatic changes with eustatic sea level are regarded as the main controlling factors that detect the depositional environment (Nesbitt, $1982 \& 1984$ and Naymushina et al., 2010). The Clay minerals are considered as a sedimentation product and provide information for the paleoclimate, provenance, and environments. Furthermore, clay minerals are extensively dispersed in sediments and are the main indicator of the paleo-environment, the different environments well-known by the clay-mineral content (Xie et al., 2010; and Sun et al., 2019 and Abd-Elaty et. al., 2020). The study area lies between Latitudes $25^{\circ} 10^{\prime}$ and $26^{\circ} 00^{\prime} \mathrm{N}$ and Longitudes $26^{\circ} 30^{\prime}$ and $29^{\circ} 20^{\prime} \mathrm{E}$, covers about $5625 \mathrm{Km}^{2}$ (Fig. 1) and is situated in the Dakhla basin, it shows lateral many facies variations (El-Azabi and El-Araby, 2000). The Dakhla Oasis is accessible through the east asphaltic road, which starts from the Kharga Oasis in the east of about $180 \mathrm{~km}$. to the west. The wide extended clay deposits exposed all over the El Kharga and El Dakhla stretch give attention to the government and scientists. Among the clay deposits are the black shales, which have considerable economic importance due to their special composition. The Dakhla Formation type locality, the northern bordering the Dakhla Oasis, where its thickness reaches $250 \mathrm{~m}$. The shale is accommodated chiefly in the Campanian-Maastrichtian Dakhla and Duwi formations. In the present study, the shales geochemistry and mineralogy, especially clay minerals, are used to estimate the environments and provenance. The novelty in the present study, the shale is represented different stratigraphic ages, Dakhla shales (Maastrichtian-Danian), Duwi (Campanian), and Quseir (pre-Campanian) formations and also various locations, Seven representative surface sections from Dakhla Oasis were measured, chemically and mineralogical analysed (Fig. 1). 


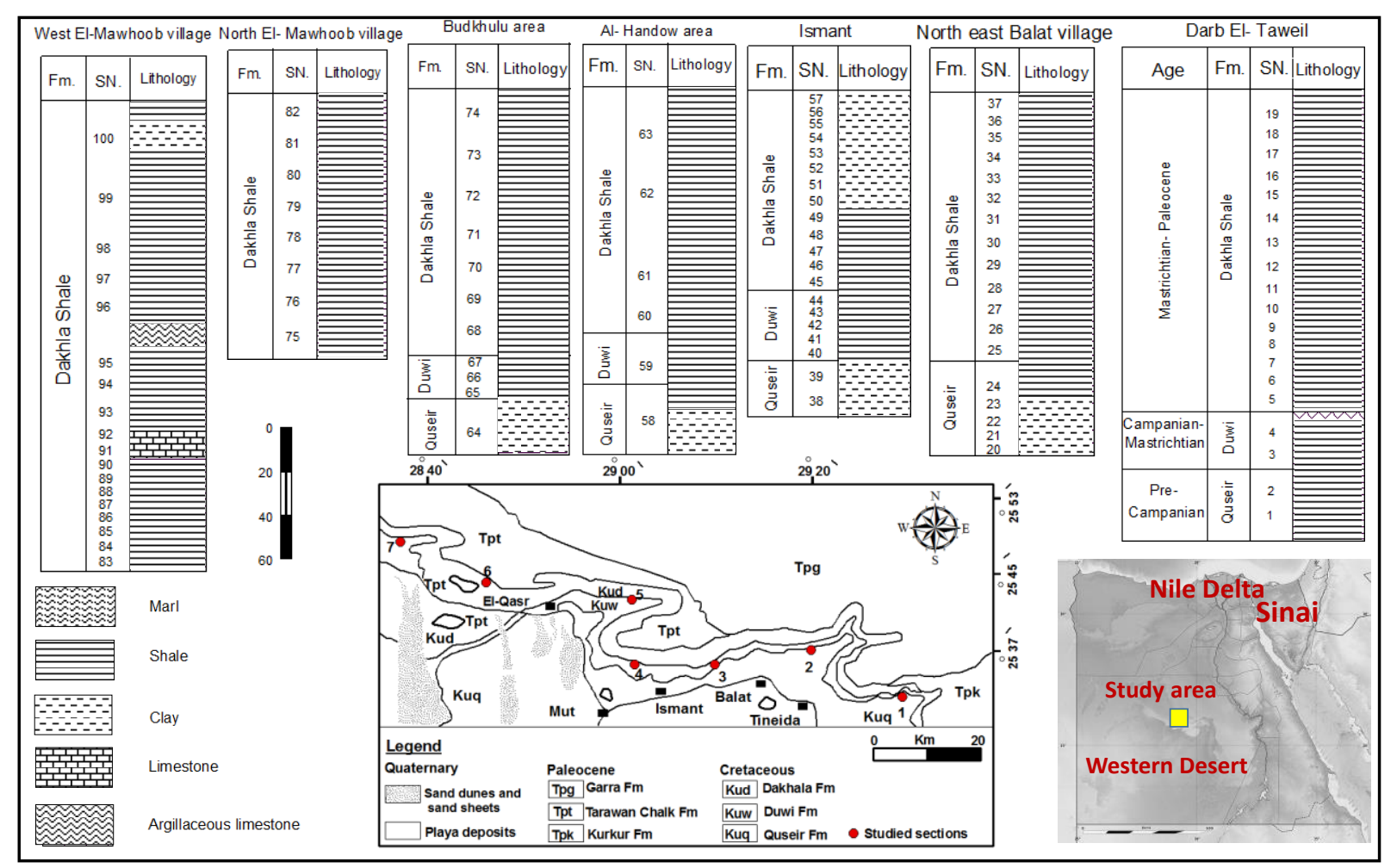

Fig.1. Sketch location map for the stratigraphic sections, Dakhla Oasis, Egypt

\section{Geologic Settings}

More researchers have been studied the study area of geology, such as (Tantawy et al., 2001), (Sediek and Amer, 2001), (Abdou and Shehata, 2007), and (Brookes, 2010). These studies are revealed that Quseir Formation founded at the succession base and composed of siltstone, variegated claystone and sandstone (Youssef, 1957). The shale of the Quseir Formation consists of shale and claystone with minor interbedded sandstone streaks and pockets. The average thickness ranges from 20-37 ms. Overlying Middle Campanian (Quseir Formation) is the Duwi Formation phosphate-bearing (Youssef, Op. Cit). It is mainly composed of alternating beds of phosphate, shale and marly limestone. The Duwi Formation is overlain conformably by a thick shale succession with mudstone interbeds of the Dakhla Formation. The Dakhla Formation is of Maastrichtian-Danian age; it and its correlative Khoman Chalk are followed upwards by the Tarawan and Esna formations, respectively. The sequence is dominated by many lithologic varieties, including shale, sandstone, claystone, limestone, phosphorite with various micro-and macrofossils assemblages. The studied sections it is composed of the argillaceous limestone at the base, followed by fissile grey shale with alternating bands of fossiliferous mudstone, wherein the upper part of the sequence is composed of grey and purple shales alternating with yellowish-brown ferruginous sandy limestone. The Dakhla Formation thickness range from 70-180 m; it marks the thickest and widespread shale unit throughout the Upper Cretaceous-Lower Tertiary sediments all over Egypt. At north and west, El-Mawhoob Village base is unexposed.

\section{Materials and Methods}

Seven sections (Darb El-Taweil; Ismant; Northeast Balat Village; El Handow; Budkhulu; North El-Mawhob Village, and West El-Mawhoob) of the pre-Campanian to Danian rocks were sampled (Fig. 1). The measured successions are mainly composed of shales and mixed siliciclastic and carbonate rocks, of which the phosphorite is dominant in the basal and middle parts of the Duwi Formation, whereas the carbonates comprise the main bulk of the upper part in the Duwi Formation (Fig.1). About 101 samples representing the different ages of study shales (10 from Quseir Formation, 11 from Duwi Formation and 80 from Dakhla Shale) were collected and chemically analysed for $\mathrm{SiO}_{2}, \mathrm{MgO}, \mathrm{Al}_{2} \mathrm{O}_{3}, \mathrm{MnO}, \mathrm{Fe}_{2} \mathrm{O}_{3}, \mathrm{CaO}, \mathrm{Na}_{2} \mathrm{O}, \mathrm{K}_{2} \mathrm{O}, \mathrm{P}_{2} \mathrm{O}_{5}, \mathrm{Cl}-, \mathrm{SO}_{3^{--}}$, TOC and $\mathrm{TiO}_{2}$. The samples are tested, 200-300 $\mathrm{mg}$ of as a powder in Teflon beakers with a mixture of perchloric, hydrofluoric, and nitric acids. The mixtures were diluted by hydrochloric acid. The total iron is expressed as FeO. The limits for the analysed elements are mostly around $0.01 \mathrm{ppm}$. The range of accuracy (Analytical uncertainties) is $2 \%$ for all major oxides except P2O5 and $\mathrm{MnO}$, for which uncertainties can be $+/-10 \%$. The results are compared with the Phanerozoic Shale average composition (Condie, 1993), Normal Pierre Shale (Schultz et al., 1980), (UCC) Upper Continental Crust (Taylor and McLennan, 1985), Russian Mesozoic and Cenozoic Shales (RMCS) 
(Ronov and Migdisov, 1971) and (NASC) North American Shale Composite (Gromet et al., 1984). The Chemical Index of Alteration (CIA) was calculated (Nesbitt and Young, 1982). The index represents the molar ratios of $\left(\mathrm{Al}_{2} \mathrm{O}_{3} /\left(\mathrm{Al}_{2} \mathrm{O}_{3}+\mathrm{CaO}+\mathrm{K}_{2} \mathrm{O}+\mathrm{Na}_{2} \mathrm{O}\right) \times 100\right.$, which has been established as a general indicator for the weathering degree (Nesbitt and Young, 1982). High values (76-100) indicate intensive chemical weathering in the source area, whereas low values of 50 or less indicate un-weathered areas. They reported a CIA value of nearly $100 \%$ for kaolinite and chlorite, and 70 to $75 \%$ for moderate or average shales, whereas Taylor and McLennan (1985) reported a CIA value of 85 to $100 \%$ for residual clays. The chemical index of weathering (CIW) is calculated $\left(\mathrm{Al}_{2} \mathrm{O}_{3} /\left(\mathrm{Al}_{2} \mathrm{O}_{3}+\mathrm{CaO}+\mathrm{Na}_{2} \mathrm{O}\right) \times 100\right.$. Where, $\mathrm{Al}_{2} \mathrm{O}_{3}, \mathrm{CaO}$, and $\mathrm{Na}_{2} \mathrm{O}$ are in molecular proportions. In the proposed index, $\mathrm{Al} 2 \mathrm{O} 3$ is used as the immobile component. $\mathrm{CaO}$ and $\mathrm{Na}_{2} \mathrm{O}$ are considered as mobile constituents because they are free leaked during weathering. Additionally, (ICV) Index compositional variation was used for sediments maturity determination (Cox et al., 1995), sediments show ICV (>1) are immature with the first cycle of sediments deposited in tectonically whereas, ICV $(<1)$ are mature and deposited in craton environment, where the recycling of sediment is active.

Therefore, the clay portions were subjected to X-Ray diffraction analysis to identify their clay mineral composition (Carroll, 1970). Three oriented mounts were prepared from each sample: untreated, glycolated and heated at $600 \mathrm{o} \mathrm{C}$ for one hour. Semi-quantitative detection of the identified clay minerals was undertaken with the method adopted by (Pierce and Siegel, 1969). X-Ray diffractograms were obtained using Philips X-Ray diffractometer model $\mathrm{PW} / 1710$ with a monochromator, $\mathrm{Cu}$-radiation $(\lambda=0.1542 \mathrm{~nm})$ operating at $40 \mathrm{KV}, 30$ $\mathrm{mA}$. The diffraction forms are collected at $25^{\circ} \mathrm{C}$ with step size $0.05^{\circ}$ per step and a dwell time of $12 \mathrm{~s}$ per increment. As well as, shale samples were investigated by different techniques to evaluate their mineral compositions. They were studied by using differential thermal techniques (Ramachandran et al., 2002). The thermal analyses were done by mean of MOM Derivatograph, which gives the differential thermal analysis (DTA) and the Thermal Gravimetry (TG). One gram of each powdered sample was heated by $10 \mathrm{Co} / \mathrm{min}$ up to $950 \mathrm{Co}$ with $\alpha-\mathrm{Al}_{2} \mathrm{O}_{3}$ as reference material. DTA sensitivities and TG were set at 1/10 and $500 \mathrm{mg}$, respectively. DTA and TG are explained by the form of derivatographs. The principal thermal reactions and the approximate temperature ranges are generally considered in low temperature below $400^{\circ} \mathrm{C}$ : loss of adsorbed water, $400-750$ ${ }^{\circ} \mathrm{C}$ : dehydroxylation and the creation of quasi-stable dehydroxylated phases and high temperature above $750^{\circ} \mathrm{C}$ up to $950^{\circ} \mathrm{C}$ : recrystallisation and formation of new phases.

\section{Results and discussion}

\section{Mineralogical composition}

The inspected samples of the Duwi, Quseir, and Dakhla Shale were studied using differential thermal techniques. The thermal analyses were conducted for 12 clay samples of different rock units. DTA and Therrmogravimetry (TG) results are explained by the form of derivatograph (Fig. 2). The characteristic thermal manners of each mineral as follow:

\section{Smectite}

DTA curves for smectite show in variable symmetric endothermic peaks at temperature ranges from $50.8 \mathrm{C}^{\circ}$ $-940.3 \mathrm{C}^{\circ}$ (Fig. 2). The total losses in weight upon heating up to $950 \mathrm{C}^{\circ}$ range from $12.64 \%$ to $20.37 \%$ of the original sample weight. All smectite yields three peaks in studied samples, the first is a peak at a lowtemperature range from 50.8 $\mathrm{C}^{\circ}$ to $100.2 \mathrm{C}^{\circ}$ (Mackenzie, 1970; and Alejandra et al., 2017), the second is a main endothermic peak at a temperature ranging between $\left(510.1 \mathrm{C}^{\circ}-525.1 \mathrm{C}^{\circ}\right)$ related to loss of hydroxyl water and the third is an endothermic reaction at a temperature ranging between $860.3 \mathrm{C}^{\circ}$ to $940 \mathrm{C}^{\circ}$ (Fig. $2 \mathrm{a}, \mathrm{d}, \mathrm{f}$ and b). The formation of smectite requires the presence of $\mathrm{Na} \& \mathrm{~K}$ (alkali metals), and silicates formed by the hydrolysis of $\mathrm{Ca}, \mathrm{Mg}$ and Fe tend to combine with silica to form smectite (Millot, 1970; and Keller, 1970).

\section{Kaolinite}

It predominates in studied Dakhla shales, but it present as a minor in Quseir and Duwi shales. It exhibits two peaks on DTA curve, the first peak is the main peak of smectite at a temperature ranging between $510.1 \mathrm{C}^{\circ}$ and $525.1 \mathrm{C}^{\circ}$ upon loss of structural water, and the second is at a temperature ranging between $860.3 \mathrm{C}^{\circ}$ and 940 $\mathrm{C}^{\circ}$ due to structural change (Fig. 2a, $\mathrm{c}$ and d). The Dakhla Formation consists of kaolinite and less of a smectite/illite mixed layer than Duwi and Quseir formations. Kaolinite is considered a weathering product and soil formation of all rocks (Frederickson, 1952). These conditions involve the removal of $\mathrm{Na}, \mathrm{K}, \mathrm{Mg}, \mathrm{Ca}$ and $\mathrm{Fe}$ and the addition of $\mathrm{H}$ (Millot, 1970 and Keller, 1970). Moreover, the end product of weathering is Kaolinite under the condition of acid soil solution and good drainage in a temperate climate (Krauskopf, 1979).

\section{Geothite}

The amorphous ferric oxide is recorded in the curves of a few samples of Quseir and Dakhla Shale. It exhibits a very small endothermic peak at a temperature range between $240 \mathrm{C}^{\circ}-280 \mathrm{C}^{\circ}$ (Fig. $2 \mathrm{a}$ ), as mentioned by (Mackanzie, 1970). After deposition iron may be leached from clay minerals which combine with hydroxyl ion to form colloidal goethite (Ehlers et al., 1982). 


\section{Calcite}

Calcite is present as a minor constituent in a few samples of Quseir and Dakhla shale. In the current study calcite, gives a single endothermic peak as mentioned by (Mackanzie, 1970) due to the decomposition of carbonate ions associated with calcium. The single endothermic peak is detected at a temperature ranging between $700 \mathrm{C}^{\circ}-735 \mathrm{C}^{\circ}$ (Fig. 2f).

\section{$\mathrm{X}$-ray diffraction analysis}

The X-ray diffraction was conducted for the oriented clay fraction (untreated). It revealed the existence of a sharp peak of $14.1 \mathrm{~A}^{\circ}$ and a very weak $7.16 \mathrm{~A}^{\circ}$. When glycolated run the peak 14.1 shifts to a larger spacing peak of $17.9 \mathrm{~A}^{\circ}$, while with heating to $550 \mathrm{C}^{\circ}$, it collapsed and sharpened at $9.8 \mathrm{~A}^{\circ}$ peak. X-ray analysis of 35 samples revealed that smectite range from $35 \%$ to $85 \%$, while kaolinite (0-75\%), consequently illite - smectite mixed layer and quartz $(6.5 \%$ to $15 \%)$ other than calcite and goethite occur as minor constituents (Table 1). Goethite and calcite were detected in minor amounts in study samples. As a whole, the shale are generally composed of smectite, kaolinite and smectite/ illite mixed layer. The second dominant clay constituent is Kaolinite, besides occasional goethite and calcite. The Dakhla shale is comparatively more kaolinitic and less of a smectite and smectite/illite mixed layer than Duwi and Quseir formations.

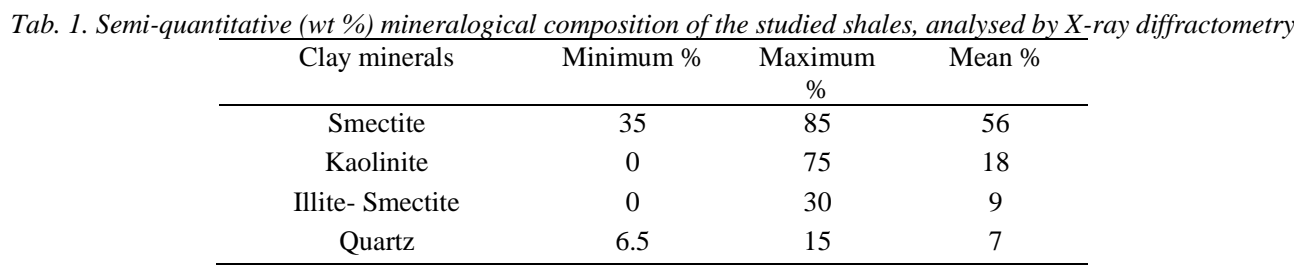

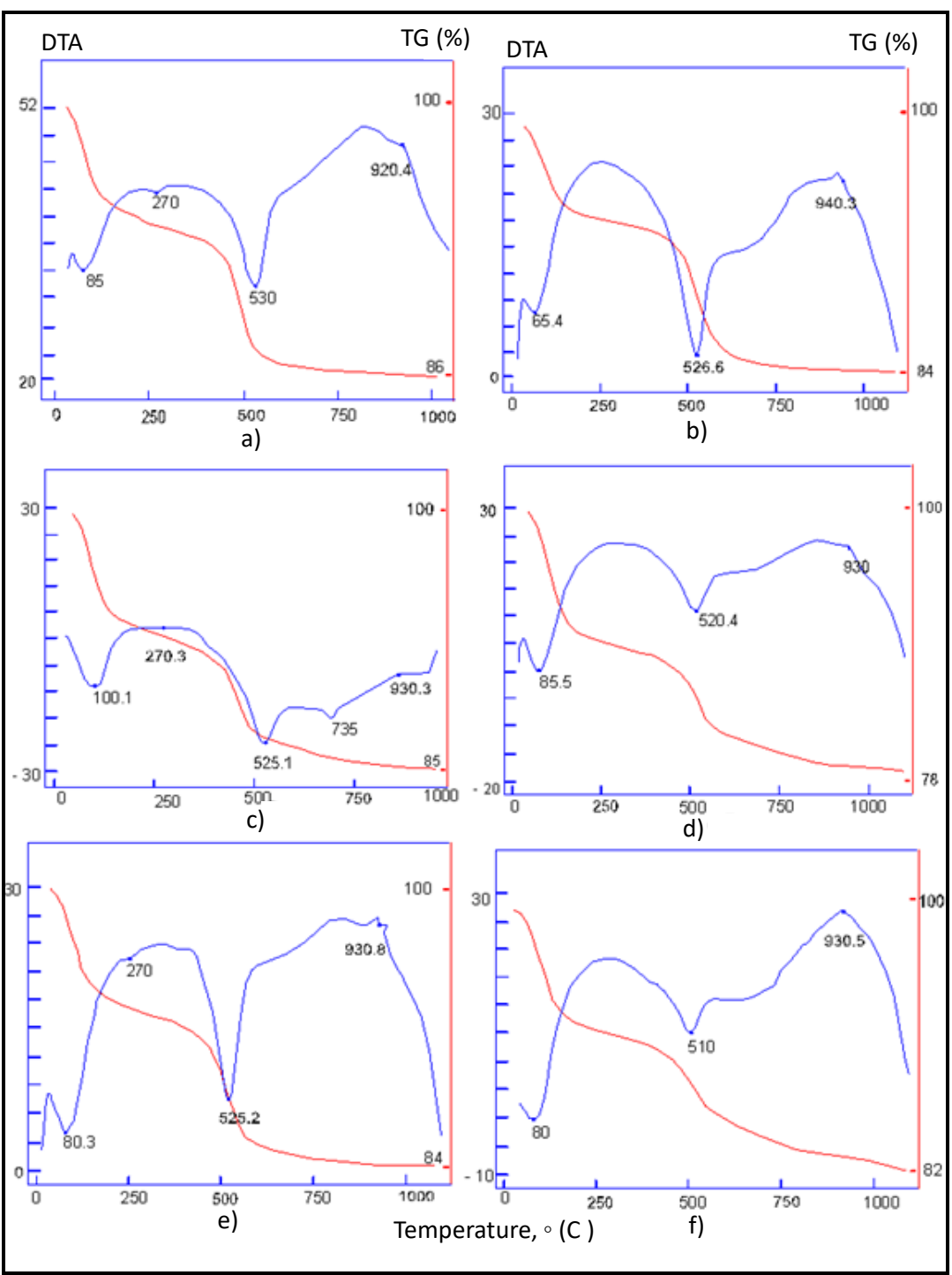

Fig.2. DTA and TG curves. Blue line for DTA and red line for TG. $a, b$ and $c$ for Dakhla Shales, $d$ and e for Duwi samples and ffor Qusier) 


\section{Geochemical composition}

\section{Elemental concentrations}

The chemical analysis of 101 samples which are represented Qusier, Duwi and Dakhla Shale. Geochemical analysis data of these samples are shown in Tables (2, 3 and 4) and Figure 3. $\mathrm{Al}_{2} \mathrm{O}_{3}$ and $\mathrm{SiO}_{2}$ are more common in Duwi, Qusier, and Dakhla shales averaging 55.31\%, 55.59\% and 47.73\%, respectively (Table 1). While, the concentrations of $\mathrm{Al}_{2} \mathrm{O}_{3}$ and $\mathrm{SiO}_{2}$ for (UC) and NASC $(66 \%$ and $64.82 \%$ for $\mathrm{SiO} 2$ and $15.2 \%$ and $16.92 \%$ for $\mathrm{Al}_{2} \mathrm{O}_{3}$ ) are lower (Taylor and McLennan, 1985; and Gromet et al., 1984). Shale in Quseir and Duwi formations are slightly more enrichment in $\mathrm{SiO}_{2}$, and relatively around the standard average for Pettijohn, 1975 and Turekian \& Wedephol, 1961 (58.10\% and $58.50 \%$ ), while the $\mathrm{Al}_{2} \mathrm{O}_{3}$ in Dakhla shale (20.57\%) are higher than published shale composition (Table 3). The samples were rich in major oxides as $\mathrm{SiO}_{2}, \mathrm{Al}_{2} \mathrm{O}_{3} \& \mathrm{TiO}_{2}$ and poor in $\mathrm{MgO}, \mathrm{CaO}$, and $\mathrm{K}_{2} \mathrm{O} \& \mathrm{Na}_{2} \mathrm{O}$ (Fig. 3). These elements show discordance when compared with the known world shale; Upper Crust (Taylor and McLennan, 1985), North American Shale Composite (NASC, Gromet et al., 1984). Meanwhile, these elements relatively show concordance with Pettijohn, 1975 and Turekian \&Wedephol, 1961 (Table 3). The high correlation coefficients between $\mathrm{SiO}_{2}$ and $\mathrm{Al}_{2} \mathrm{O}_{3}, \mathrm{Fe}_{2} \mathrm{O}_{3}, \mathrm{TiO}_{2}$ and $\mathrm{MgO}(\mathrm{r}$ $=0.97,0.90,0.96$ and 0.73 ; respectively) and moderate correlation with $\mathrm{K}_{2} \mathrm{O}(\mathrm{r}=0.43)$ (Table 4) suggest the occurrence of these oxides in common phases, most likely clay minerals. The moderate correlations $\left(\mathrm{Al}_{2} \mathrm{O}_{3}\right.$ with $\mathrm{K}_{2} \mathrm{O}$ and $\mathrm{Na}_{2} \mathrm{O}(\mathrm{r}=0.37$ and 0.24 ; respectively) are explained due to minor illite concentrations and recommend that the main amount of $\mathrm{Na}$ and $\mathrm{K}$ occurs in clay minerals. $\mathrm{CaO}$ exhibits a strong positive relationship with TOC $\mathrm{r}=0.71$, Table 4), indicating that the main part of $\mathrm{Ca}$ exists in carbonate minerals. According to the geochemical classification, which depends on the log values of the ratios $\mathrm{SiO}_{2} / \mathrm{Al}_{2} \mathrm{O}_{3}$ and $\mathrm{Fe}_{2} \mathrm{O}_{3} / \mathrm{K}_{2} \mathrm{O}$ (Herron, 1988), the black shale is classified into iron-shale.

Tab. 2. Ranges of the major elements concentration in studied shales

\begin{tabular}{|c|c|c|c|c|c|c|c|c|c|c|c|c|c|c|}
\hline Age & Formation & $\mathrm{SiO}_{2}$ & $\mathrm{Al}_{2} \mathrm{O}_{3}$ & $\mathrm{Fe} 2 \mathrm{O} 3$ & $\mathrm{MnO}$ & $\mathrm{MgO}$ & $\mathrm{CaO}$ & $\mathrm{Na}_{2} \mathrm{O}$ & $\mathrm{K}_{2} \mathrm{O}$ & $\mathrm{P}_{2} \mathrm{O}_{5}$ & $\mathrm{Cl}-$ & SO3-- & TOC & $\mathrm{TiO}_{2}$ \\
\hline \multirow[t]{2}{*}{$\begin{array}{l}\text { Maastrichtian } \\
\text { - Paleocene }\end{array}$} & \multirow[t]{2}{*}{$\begin{array}{l}\text { Dakhla } \\
\mathrm{N}=(92)\end{array}$} & $\begin{array}{r}1.4- \\
69.51 \\
\end{array}$ & $\begin{array}{c}0.4- \\
25.55\end{array}$ & $\begin{array}{c}0.93- \\
9.94\end{array}$ & $\begin{array}{c}0.00 \\
7- \\
2.13 \\
\end{array}$ & $0-3$ & $\begin{array}{c}0.19- \\
51.5\end{array}$ & $\begin{array}{l}0.12- \\
19.29\end{array}$ & $\begin{array}{c}0.08- \\
1.69\end{array}$ & $\begin{array}{c}0.07 \\
- \\
1.75 \\
\end{array}$ & $\begin{array}{c}0- \\
2.09\end{array}$ & $\begin{array}{c}0- \\
5.01\end{array}$ & $\begin{array}{c}0- \\
41.6\end{array}$ & $\begin{array}{l}0.03- \\
21.24\end{array}$ \\
\hline & & 47.16 & 20.57 & 6.43 & 0.88 & 0.49 & 2.1 & 1.69 & 0.71 & 0.75 & 0.2 & 1.38 & 4.26 & 12.81 \\
\hline \multirow[t]{2}{*}{$\begin{array}{l}\text { Campanian - } \\
\text { Maastrichtian }\end{array}$} & \multirow[t]{2}{*}{$\begin{array}{c}\text { Duwi } \\
\mathrm{N}=(11)\end{array}$} & $\begin{array}{c}46.25 \\
- \\
73.61 \\
\end{array}$ & $\begin{array}{l}7.78- \\
17.87\end{array}$ & $\begin{array}{l}2.65- \\
8.28\end{array}$ & $\begin{array}{c}0.02 \\
- \\
8.28\end{array}$ & $0-1.3$ & $\begin{array}{l}0.01- \\
3.32\end{array}$ & $0-4.68$ & $\begin{array}{c}0.14- \\
1.99\end{array}$ & $\begin{array}{c}0.09 \\
- \\
1.67\end{array}$ & $\begin{array}{c}0.02 \\
- \\
1.39\end{array}$ & $\begin{array}{c}0.06- \\
2.87\end{array}$ & $\begin{array}{c}0.15- \\
11.7\end{array}$ & $\begin{array}{c}1.1- \\
17.17\end{array}$ \\
\hline & & 55.59 & 14.85 & 5 & 1.42 & 0.24 & 1.7 & 1.55 & 1.16 & 0.96 & 0.41 & 1.45 & 2.4 & 11.78 \\
\hline \multirow[t]{2}{*}{$\begin{array}{c}\text { Pre- } \\
\text { Campanian }\end{array}$} & \multirow[t]{2}{*}{$\begin{array}{l}\text { Qusier } \\
\mathrm{N}=(10)\end{array}$} & $\begin{array}{c}36.91 \\
- \\
70.45 \\
\end{array}$ & $\begin{array}{l}9.68- \\
17.62\end{array}$ & $\begin{array}{l}3.5- \\
9.8\end{array}$ & $\begin{array}{c}0.49 \\
- \\
1.95\end{array}$ & $\begin{array}{c}0.01- \\
0.27\end{array}$ & $\begin{array}{l}0.14- \\
10.52\end{array}$ & $\begin{array}{l}0.38- \\
10.05\end{array}$ & $\begin{array}{c}0.33- \\
3.72\end{array}$ & $\begin{array}{c}0.41 \\
- \\
4.69\end{array}$ & $\begin{array}{c}0.03 \\
- \\
0.29\end{array}$ & $\begin{array}{c}0.21- \\
1.83\end{array}$ & $\begin{array}{c}0- \\
0.05\end{array}$ & $\begin{array}{l}7.52- \\
22.21\end{array}$ \\
\hline & & 55.31 & 12.75 & 6.76 & 1.07 & 0.08 & 2.79 & 0.18 & 1.07 & 2.31 & 0.18 & 0.54 & 0.19 & 13.83 \\
\hline
\end{tabular}

Tab. 3. Comparison of the average composition of the studied shales with published average shales ( $N$ is the number of samples)

\begin{tabular}{|c|c|c|c|c|c|c|c|}
\hline \multirow[b]{2}{*}{ Composition } & \multicolumn{3}{|c|}{ Present Study } & \multirow{2}{*}{$\begin{array}{c}\text { UC } \\
\text { (Taylor and } \\
\text { McLennan, } \\
1985 \text { ) }\end{array}$} & \multirow{2}{*}{$\begin{array}{c}\text { NASC } \\
\text { (Gromet et al., } \\
1984)\end{array}$} & \multirow{2}{*}{$\begin{array}{c}\text { Pettijohn } \\
\text { (1975) }\end{array}$} & \multirow{2}{*}{$\begin{array}{l}\text { Turekian and } \\
\text { Wedephol, } \\
\text { (1961) }\end{array}$} \\
\hline & $\begin{array}{c}\text { Dakhla } \\
\text { Shale } \\
\mathrm{N}=80\end{array}$ & $\begin{array}{l}\text { Duwi } \\
\mathrm{N}=11\end{array}$ & $\begin{array}{l}\text { Quseir } \\
\mathrm{N}=10\end{array}$ & & & & \\
\hline $\mathrm{SiO}_{2}$ & 47.73 & 55.59 & 55.31 & 66.00 & 64.82 & 58.10 & 58.50 \\
\hline $\mathrm{Al}_{2} \mathrm{O}_{3}$ & 20.57 & 14.85 & 12.75 & 15.20 & 16.90 & 15.4 & 15.00 \\
\hline $\mathrm{Fe}_{2} \mathrm{O}_{3}$ & 6.43 & 5.00 & 6.76 & 5.00 & 5.65 & n.a. & 0.77 \\
\hline $\mathrm{MnO}$ & 0.88 & 1.42 & 1.07 & 0.08 & 0.06 & 4.02 & 4.72 \\
\hline $\mathrm{MgO}$ & 0.49 & 0.24 & 0.08 & 2.20 & 2.86 & 2.44 & 2.50 \\
\hline $\mathrm{CaO}$ & 2.10 & 1.70 & 2.79 & 4.20 & 3.63 & 3.11 & 3.10 \\
\hline $\mathrm{Na}_{2} \mathrm{O}$ & 1.69 & 1.55 & 2.35 & 3.90 & 1.14 & 1.30 & 1.30 \\
\hline $\mathrm{K}_{2} \mathrm{O}$ & 0.71 & 1.16 & 1.07 & 3.40 & 3.97 & 3.24 & 3.10 \\
\hline $\mathrm{P}_{2} \mathrm{O}_{5}$ & 0.75 & 0.96 & 2.31 & - & 0.13 & n.a. & 0.16 \\
\hline $\mathrm{Cl}-$ & 0.20 & 0.41 & 0.18 & - & - & - & - \\
\hline $\mathrm{SO}_{3}^{-}$ & 1.38 & 1.45 & 0.54 & - & - & - & - \\
\hline TOC & 4.26 & 2.40 & 0.19 & - & - & - & - \\
\hline $\mathrm{TiO}_{2}$ & 12.81 & 11.78 & 13.83 & 0.50 & 0.80 & n.a. & 0.77 \\
\hline
\end{tabular}



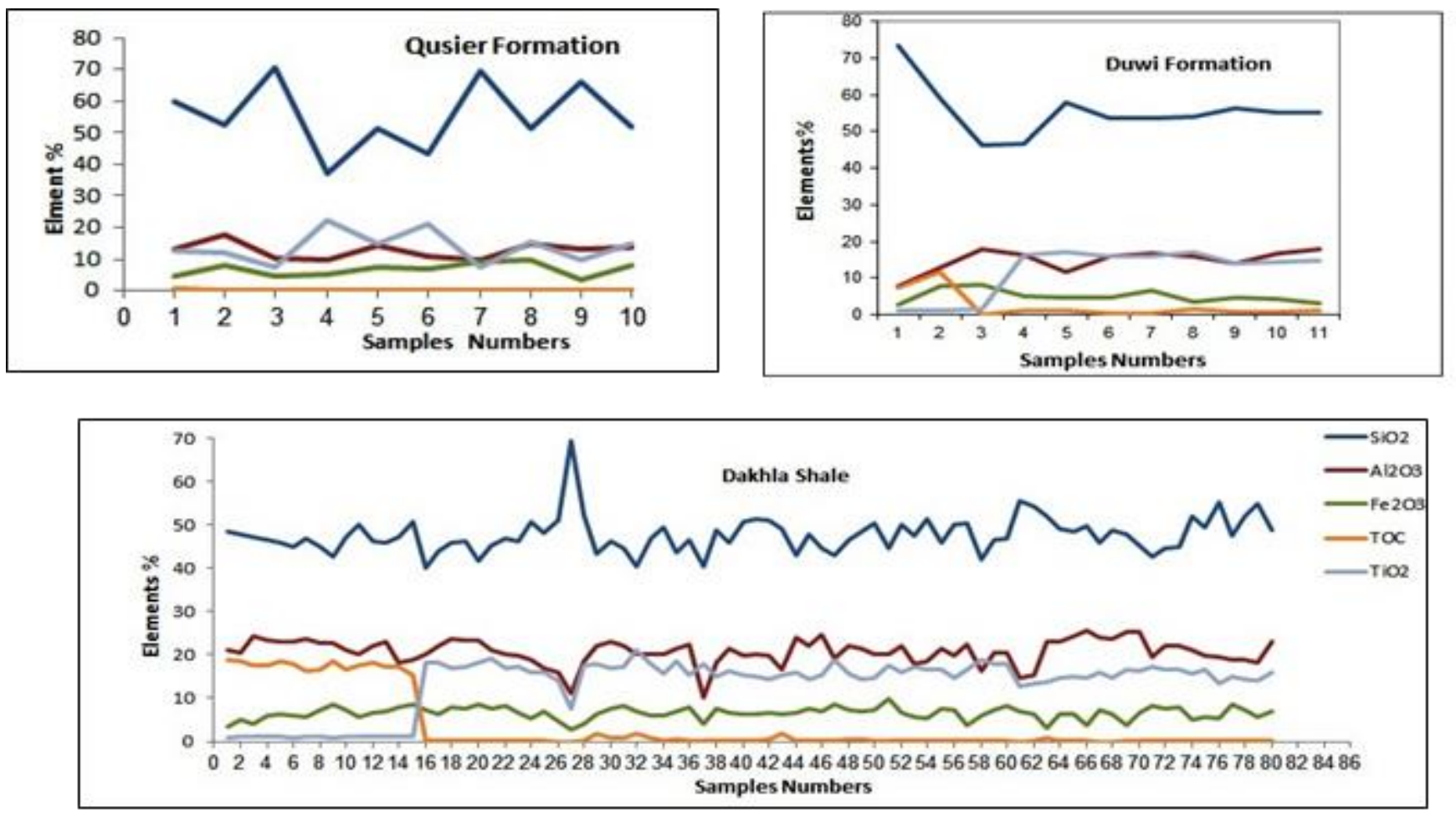

Fig. 3. Geochemical composition of studied shales

Tab. 4. Correlation coefficients of the major elements

\begin{tabular}{|c|c|c|c|c|c|c|c|c|c|c|c|c|c|}
\hline & $\mathrm{SiO} 2$ & $\mathrm{Al}_{2} \mathrm{O}_{3}$ & $\mathrm{Fe}_{2} \mathrm{O}_{3}$ & $\mathrm{TiO}_{2}$ & $\mathrm{MnO}$ & $\mathrm{MgO}$ & $\mathrm{CaO}$ & $\mathrm{Na}_{2} \mathrm{O}$ & $\mathrm{K}_{2} \mathrm{O}$ & $\mathrm{P}_{2} \mathrm{O}_{5}$ & $\mathrm{Cl}-$ & $\mathrm{SO}_{3}^{--}$ & TOC \\
\hline $\mathrm{SiO}_{2}$ & 1 & & & & & & & & & & & & \\
\hline $\mathrm{Al}_{2} \mathrm{O}_{3}$ & 0.97 & 1 & & & & & & & & & & & \\
\hline $\mathrm{Fe}_{2} \mathrm{O}_{3}$ & 0.90 & 0.96 & 1 & & & & & & & & & & \\
\hline $\mathrm{TiO}_{2}$ & 0.96 & 0.95 & 0.87 & 1 & & & & & & & & & \\
\hline $\mathrm{MnO}$ & 0.54 & 0.53 & 0.61 & 0.60 & 1 & & & & & & & & \\
\hline $\mathrm{MgO}$ & 0.73 & 0.77 & 0.83 & 0.73 & 0.46 & 1 & & & & & & & \\
\hline $\mathrm{CaO}$ & -0.18 & -0.17 & -0.13 & -0.17 & -0.09 & 0.31 & 1 & & & & & & \\
\hline $\mathrm{Na}_{2} \mathrm{O}$ & 0.44 & 0.24 & 0.78 & 0.79 & 0.36 & 0.65 & 0.03 & 1 & & & & & \\
\hline $\mathrm{K}_{2} \mathrm{O}$ & 0.43 & 0.37 & 0.87 & 0.89 & 0.64 & 0.69 & -0.01 & 0.8 & 1 & & & & \\
\hline $\mathrm{P}_{2} \mathrm{O}_{5}$ & 0.27 & 0.28 & 0.07 & 0.26 & -0.02 & -0.06 & -0.06 & 0.45 & 0.19 & 1 & & & \\
\hline $\mathrm{Cl}-$ & 0.58 & 0.46 & 0.46 & 0.46 & 0.14 & 0.39 & -0.01 & 0.42 & 0.62 & -0.09 & 1 & & \\
\hline $\mathrm{SO}_{3--}^{--}$ & 0.18 & 0.18 & 0.02 & 0.16 & -0.01 & 0.21 & 0.61 & 0.47 & 0.23 & 0.72 & 0.07 & 1 & \\
\hline TOC & 0.55 & 0.57 & 0.55 & 0.54 & 0.31 & 0.82 & 0.71 & 0.60 & 0.63 & 0.12 & 0.39 & 0.62 & 1 \\
\hline
\end{tabular}

On the triangular (A-Si-CM) $\mathrm{Al}_{2} \mathrm{O}, \mathrm{SiO}_{2}$, and $\mathrm{CaO}+\mathrm{MgO}$; the studied samples can be classified as silty shales (Fig.4). The sediments plot relative coincides with Pettijohn (1975) and Turekian \& Wedephol (1961) standards. The major element analyses of the studied samples compared to (UC) Taylor and McLennan (1985) and (NASC) Gromet et al. (1984); Pettijohn (1975) and Turekian and Wedephol (1961) Table (3). This table shows variation in the major element content for all analysed samples. For example, the $\mathrm{SiO}_{2}$ contents range from 47.16 to $55.59 \mathrm{wt} \%$, the $\mathrm{TiO}_{2}$ content from 11.78 to $13.83 \mathrm{wt} \%$, the $\mathrm{Al}_{2} \mathrm{O}_{3}$ content from 12.75 to $20.57 \mathrm{wt} \%$, and the $\mathrm{Fe}_{2} \mathrm{O}_{3}$ content ranges from 5 to $6.76 \mathrm{wt} \%$. The contents of $\mathrm{MgO}, \mathrm{CaO}$, and $\mathrm{MnO}$ are low. The $\mathrm{Na}_{2} \mathrm{O}$ and $\mathrm{K} 2 \mathrm{O}$ contents range from 1.39 to $2.35 \mathrm{wt} \%$ and from 0.71 to $1.16 \mathrm{wt} \%$, respectively. Nesbitt and Young (1982, $1984,1989 \& 1996)$ and Nesbitt et al. (1996) used the ternary diagrams (Fig. 5) $\mathrm{Al}_{2} \mathrm{O}_{3}-\left(\mathrm{CaO}+\mathrm{Na}_{2} \mathrm{O}\right)-\mathrm{K}_{2} \mathrm{O}(\mathrm{A}-$ $\mathrm{CN}-\mathrm{K})$ and $\mathrm{Fe}_{2} \mathrm{O}_{3}+\mathrm{MgO}-\left(\mathrm{CaO}+\mathrm{Na}_{2} \mathrm{O}+\mathrm{K}_{2} \mathrm{O}\right)-\mathrm{Al}_{2} \mathrm{O}_{3}$ (A-CNK-FM) to deduce weathering trends. On both the A-CN-K triangular diagram (Fig. 6) and the A-CNK-FM diagram (Fig. 7), high $\mathrm{Al}_{2} \mathrm{O}_{3}$ contents, intensive weathering history. Weathering has occurred when the alkali elements decreased or detached from the sediments.

\section{Weathering conditions}

The CIA is calculated, $\left[\left(\mathrm{CIA}=100 \times\left(\mathrm{Al}_{2} \mathrm{O}_{3} /\left(\mathrm{Al}_{2} \mathrm{O}_{3}+\mathrm{CaO}+\mathrm{Na}_{2} \mathrm{O}+\mathrm{K}_{2} \mathrm{O}\right)\right]\right.\right.$ according to Harnois (1988) has been established as a general indicator for the weathering degree in a provenance region (Nesbitt and Young, 
1982). The CIA of the sediments ranges from $59.23 \%$ to $94.83 \%$. However, the average value for (Qusier Formation) is $74.68 \%, 77.13 \%$ for Duwi Formation and for Dakhla Shale is $84.57 \%$ (Table 4), which is high compared to UC, and NASC, indicating a moderate to high weathering degree. The studied Dakhla Shale was founded on intensive weathering than Duwi and Quseir formations. The CIW is calculated, [ $\left(\mathrm{CIW}=\left(\mathrm{Al}_{2} \mathrm{O}_{3}\right)\right.$ $\left.\left(\mathrm{Al}_{2} \mathrm{O}_{3}+\mathrm{CaO}+\mathrm{Na}_{2} \mathrm{O}\right)\right] \times 100$. In studied shales, CIW averages $80.36 \%, 81.97 \%$ and $87.83 \%$ for Qusier, Duwi and Dakhla Shales, respectively (Table 4). It is high equivalent to standard average percentages, suggesting moderate to intensive chemical weathering. The CIA and CIW high values (Table 4) imitates the presence of clay minerals and the absence of feldspars. This is also confirmed by the smectite dominance and subordinate kaolinite in these formations.

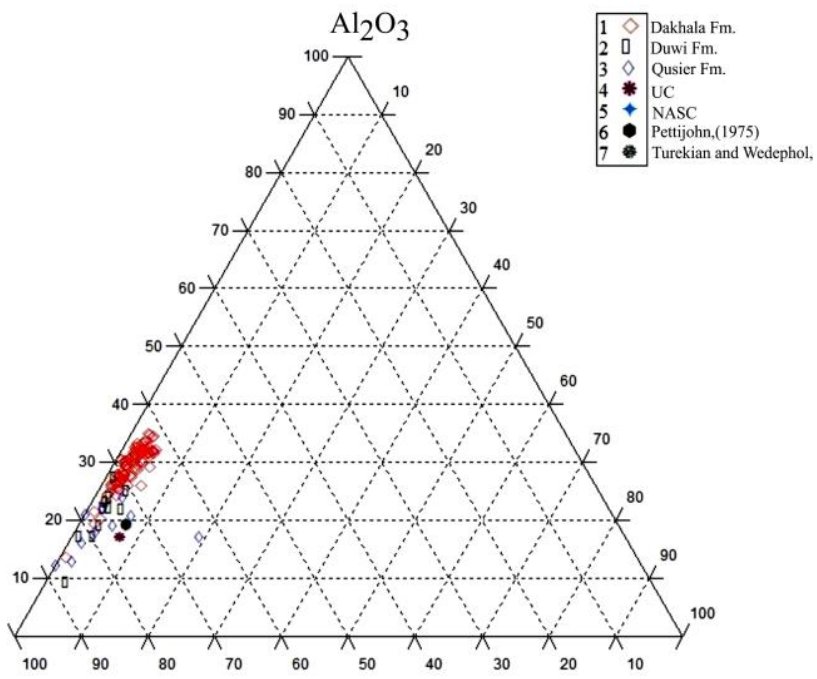

$\mathrm{SiO}_{2}$
$\mathrm{CaO}+\mathrm{MgO}$

Fig. 4. A-Si-CM Triangular showing plot of studied samples and standards sediment samples

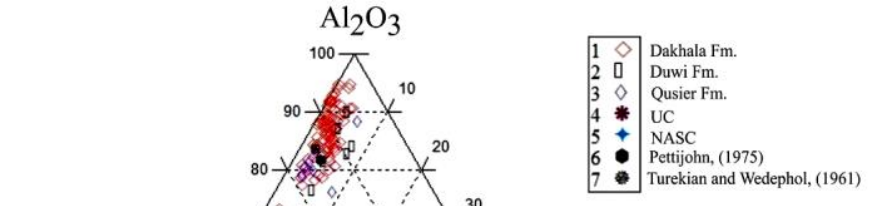

Fig. 5. A-CN-K Triangular showing plot of studied samples and standards sediment samples

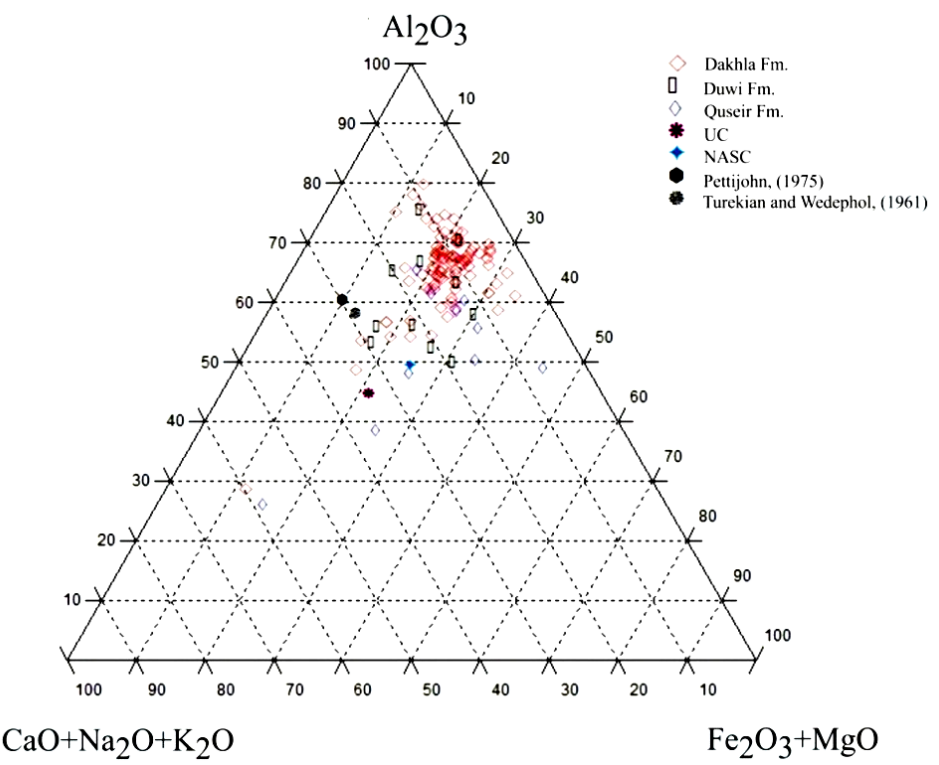

Fig. 6. A-CNK-FM Triangular showing plot of studied samples and standards sediment samples 
Tab. 5. Chemical index of weathering (CIW), chemical indices of alterations (CIA) and discrimination functions (F1 and F2) calculated for the studied shale samples

\begin{tabular}{cccccc}
\hline Age & Formation & CIW & CIA & F1 & F2 \\
\hline \multirow{2}{*}{ Maastrichtian - Paleocene } & $\begin{array}{c}\text { Dakhla } \\
\mathrm{N}=(80)\end{array}$ & $64.60-96.83$ & $59.23-94.83$ & $-1.94-10.72$ & $-8.82-30.33$ \\
\cline { 3 - 6 } & & 87.83 & 84.57 & 6.97 & 2.9 \\
\hline $\begin{array}{c}\text { Campanian - } \\
\text { Maastrichtian }\end{array}$ & $\begin{array}{c}\text { Duwi } \\
\text { N=(11) }\end{array}$ & $67.38-93.53$ & $64.41-89.79$ & $-4.54-3.87$ & $-5.06-9.49$ \\
\cline { 3 - 6 } & & 81.97 & 77.13 & 1.64 & 2.52 \\
\hline \multirow{2}{*}{ Pre-Campanian } & $\begin{array}{c}\text { Quseir } \\
\mathrm{N}=(10)\end{array}$ & $62.69-94.16$ & $64.39-88.25$ & $-0.43-8.88$ & $-3.42-23.12$ \\
\hline
\end{tabular}

\section{Interelement relations}

The Most significant observations are:

1. $\mathrm{SiO}_{2}$ show a strong correlation with $\mathrm{Al}_{2} \mathrm{O}_{3}(\mathrm{r}=0.97)$, indicating free silica presence (Fig. 7).

2. A strong correlation between $\mathrm{Fe}_{2} \mathrm{O}_{3}$ and $\mathrm{Al}_{2} \mathrm{O}_{3}(\mathrm{r}=0.96)$ in most studied shales (Fig. 8) may reflect the source of $\mathrm{Fe}_{2} \mathrm{O}_{3}$ content is detected by clay minerals and/or micas (Mishra and Sen, 2012). Both $\mathrm{Mg}$ and $\mathrm{Fe}$ contents are controlled by nonaluminous phases such as black mafic-ultramafic rock fragments and/or accessory oxide minerals. Meanwhile, major studied samples have excess sodium content related to alkali clay minerals (Fig. 9).

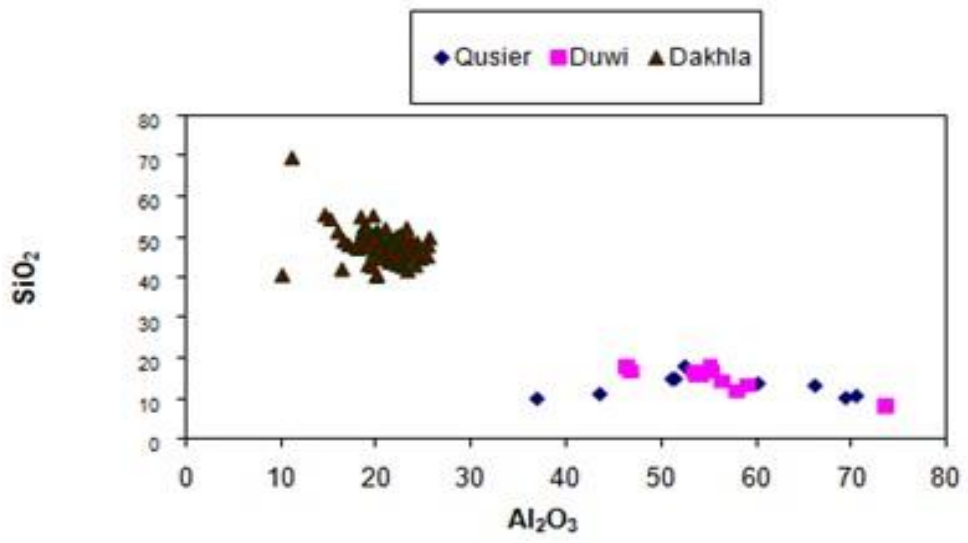

Fig. 7. Bivariant diagram of $\mathrm{SiO}_{2}$ and $\mathrm{Al}_{2} \mathrm{O}_{3}$

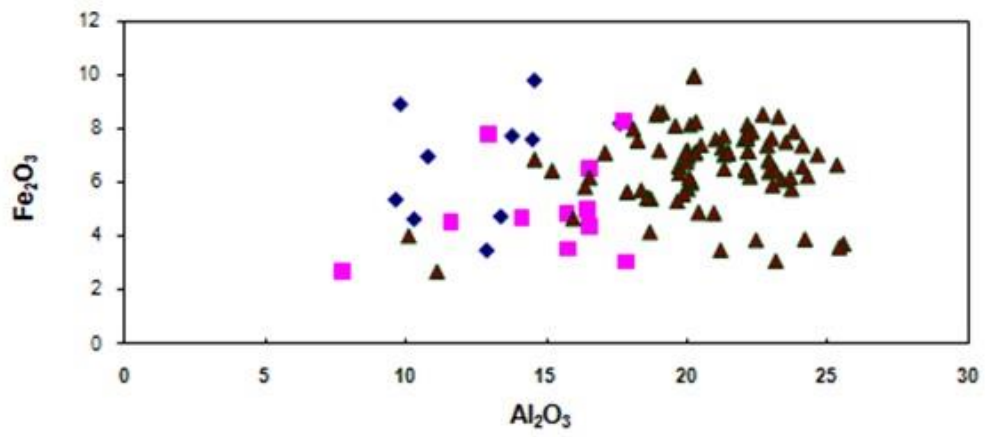

Fig. 8. Bivariant diagram of $\mathrm{Fe}_{2} \mathrm{O}_{3}$ and $\mathrm{Al}_{2} \mathrm{O}_{3}$ 


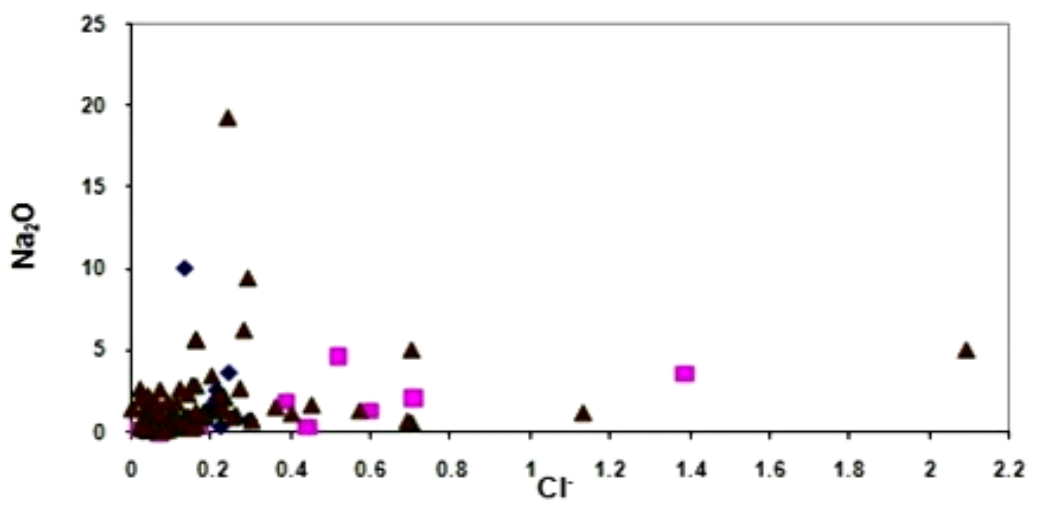

Fig. 9. Bivariant diagram of $\mathrm{Na}_{2} \mathrm{O} \%$ and $\mathrm{Cl}-\%$

\section{Sediment Maturity and climatic conditions}

The maturity and original properties of sediments, in addition to the prevailed climatic conditions be able to determine by calculating the (ICV). The ICV tends to be highest in intensive weathering minerals and lowest in steady (less weathered) minerals (Cox et al., 1995). It decreases in the smectite and lowest in the kaolinite. Additionally, more mature shale lean to low ICV values $(<1.0)$ and shales with ICV $>1$ are formed in tectonically active settings, with the initial cycle of immature sediments deposited. For the studied shales, the ICV values for Dakhla and Duwi shales are 0.59 and 0.74 , respectively (ICV < 1) and 1.24 . The shales are compositionally mature and deposited in the tectonically quiescent or cratonic environment. Whereas the Qusier shale (ICV > 1) can be incidental that are immature composition (Cox et al., 1995). To restrain the climatic condition, the proposed plot of $\mathrm{SiO}_{2}$ against $\left(\mathrm{Al}_{2} \mathrm{O}_{3}+\mathrm{K}_{2} \mathrm{O}+\mathrm{Na}_{2} \mathrm{O}\right)$. Suttner and Dutta, 1986 was used to classifying the maturity of shales for climate detection. Shales are incidental that are compositionally in arid to semi-arid climatic conditions.

\section{Provenance and depositional environment}

Geochemical limits are used to identify the provenance of the studied samples. (Amajor, 1987) utilised the $\mathrm{TiO}_{2}$ versus $\mathrm{Al}_{2} \mathrm{O}_{3}$ plot to differentiate between granitic and basaltic source rocks parent is basalt (Fig. 10) and plotting on the provenance discrimination function diagram of (Roser and Korsch 1988), illustrated in (table 5). Discriminant function $\mathrm{I}=-1.773 \mathrm{TiO}_{2}+0.607 \mathrm{Al}_{2} \mathrm{O}_{3}+0.76 \mathrm{Fe}_{2} \mathrm{O}_{3}$ (total) $-1.5 \mathrm{MgO}+0.616 \mathrm{CaO}+0.509 \mathrm{Na}_{2} \mathrm{O}$ $-1.224 \mathrm{~K}_{2} \mathrm{O}-9.09$; Discriminant function $\mathrm{II}=0.445 \mathrm{TiO}_{2}+0.07 \mathrm{Al}_{2} \mathrm{O}_{3}-0.25 \mathrm{Fe}_{2} \mathrm{O}_{3}$ (total) $-1.142 \mathrm{MgO}+$ $0.438 \mathrm{CaO}+1.475 \mathrm{Na}_{2} \mathrm{O}+1.426 \mathrm{~K}_{2} \mathrm{O}-6.861$ (Khader and McQueen, 2005). this plot on The diagram showed that predominance of considered samples fell within the P2 (intermediate igneous provenance) field of the diagram, and the rest of the samples (Darb El-Taweil section) fell within the P1 field, indicating mafic igneous provenances other than few samples fell within reworked older quartzose sediments field (Fig. 11). Furthermore, the low ratio of $\mathrm{TiO}_{2} / \mathrm{Al}_{2} \mathrm{O}_{3}$ for investigated shales indicates nearly arid climatic condition Migdisove (1960). The relationship between $\mathrm{SiO}_{2}$ and $\left(\mathrm{Al}_{2} \mathrm{O}_{3}+\mathrm{K}_{2} \mathrm{O}+\mathrm{Na}_{2} \mathrm{O}\right)$ was revealed that the samples are plot in the semiarid climate field (Fig. 12). Consequently, the combined mineralogical data, the main characters of studied shales, was formed by fluvial action, which sometimes interfered and admixed with the marine environment to create alkaline, quiet and reduced conditions. Smectite may be formed under different climatic conditions. Illite is interpreted to form in a relatively cold or dry climate, while a hot and humid climate leads to a stronger chemical weathering favouring the formation of kaolinite. Moreover, the weathering could cause a widespread and highdegree variation in clay minerals (Song et al., 2012). Consequently, it can be concluded that the abundances of smectite and, to lesser extent kaolinite in shales of the Qusier and Duwi formations sections are related to warmer with different chemical environments. Meanwhile, the abundance of kaolinite expanse of smectite indicates the end of weathering under the condition of acid soil solution and good drainage in a temperate climate. In conclusion, it is suggested that the shales deposited under fluvio-marine environments and the prevailed condition was of alkaline chemical affinity probably passed through different environments varying from the fluvial, eolian and shallow marine. 


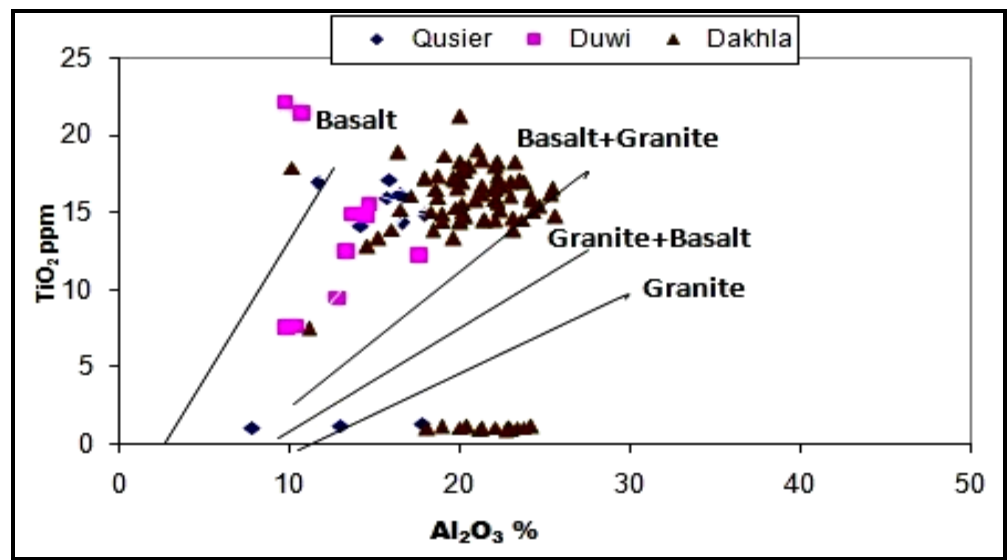

Fig. 10. $\mathrm{TiO}_{2}$ versus $\mathrm{Al}_{2} \mathrm{O}_{3}$ binary plot for studied shales (Amajor, 1987)

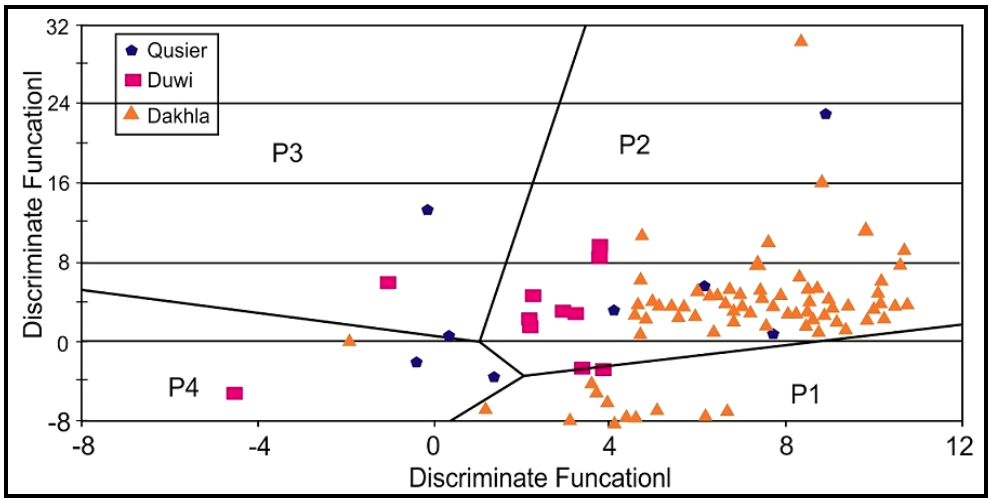

Fig. 11. Provenance-discrimination functions diagram of studied shales (after Roser and Korsch, 1988). P1 Mafic igneous provenance, P2 Intermediate igneous provenance, P3 Felsic igneous provenance and P4 Quartzose sedimentary provenance

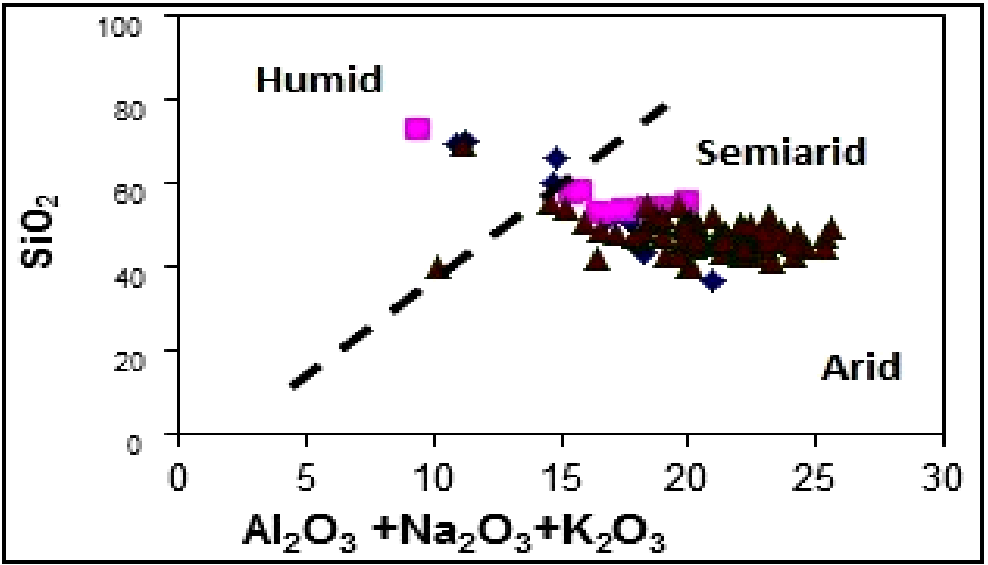

Fig. 12. $\mathrm{SiO}_{2}$ versus $\mathrm{Al}_{2} \mathrm{O}_{3}+\mathrm{Na}_{2} \mathrm{O}+\mathrm{K}_{2} \mathrm{O}$ binary plot on the diagram constructed by Suttner and Dutta (1986)

\section{Conclusion}

The studied samples are mainly composed of smectite, kaolinite, goethite and calcite. The Dakhla shale is comparatively more kaolinitic and less of smectite than the Duwi and Quseir formations. The shales were rich in $\mathrm{SiO}_{2}, \mathrm{Al}_{2} \mathrm{O}_{3} \& \mathrm{TiO}_{2}$ and poor in $\mathrm{MgO}, \mathrm{CaO}, \mathrm{K}_{2} \mathrm{O} \& \mathrm{Na}_{2} \mathrm{O}$. A strong correlation between $\mathrm{Fe}_{2} \mathrm{O}_{3}+\mathrm{MgO}$ and $\mathrm{Al}_{2} \mathrm{O}_{3}$ implied that both $\mathrm{Mg}$ and $\mathrm{Fe}$ are in part controlled by micas and/or clay minerals. The high equivalent to standard average percentages, suggesting moderate to intensive chemical weathering. The CIW and CIA high values perhaps due to the presence of clay minerals and the absence of feldspars. This is also confirmed by the smectite dominance and subordinate kaolinite in these formations. The ICV values for Dakhla and Duwi shales are 0.59 and 0.74 , respectively $(\mathrm{ICV}<1)$ and 1.24 . The shales are compositionally mature and deposited in the tectonically quiescent or cratonic environment. Whereas the Qusier shale (ICV > 1) can be incidental that are compositionally immature. The plotting of $\mathrm{SiO}_{2}$ against $\left(\mathrm{Al}_{2} \mathrm{O}_{3}+\mathrm{K}_{2} \mathrm{O}+\mathrm{Na}_{2} \mathrm{O}\right)$ was used the whole shales maturity for climate detection and are incidental compositionally in arid to semi-arid climatic conditions. The majority of shale samples distinguish between granitic and basaltic source rocks, and the parent provenances is 
basalt. Consequently, the shales are deposited under fluvio-marine environments, and the prevailed condition was of alkaline chemical affinity probably passed through different environments varying from the fluvial, eolian and shallow marine. From the economic point of view, Qusier, Duwi and Dakhla shales in the study region retain optimal conditions to be used in raw material for cement production due to the high TOC contents, low magnesium and sulphides values. Further studies are recommended on these shales exposures, such as physical and petrophysical properties, to assess the probability of their use for many industries (production of cement and ceramics).

\section{References}

Abd-Elaty, I., Pugliese, L., Zelenakova, M., Mesaros, P., Shinawi, A.E., 2020. Simulation-based solutions reducing soil and groundwater contamination from fertilizers in arid and semi-arid regions: Case study the eastern nile delta, Egypt. International Journal of Environmental Research and Public Health, 17(24), $1-18$

Abdeltawab, S., El-Mashad, M., El-Shinawi, A., 2013. Geoengineering properties of calcareous and quartzite sand collected from west Alexandria coastal line and abo rawash quarry area. Int J Sci Eng Res, 4 (11), 934-943

Abdou A.A. and Shehata, M.G., 2007. Geochemical study of the shales of Gebel Ghorabi Member, Bahariya Oasis, Western Desert, Egypt. Australian Journal of Basic and Applied Sciences, 1, 535-560

Alejandra María Zambrano Arévalo, Grey Cecilia Castellar Ortega, William Andrés Vallejo Lozada, 2017. Conceptual approach to thermal analysis and its main applications. Prospect. Vol. 15, No. 2, 117-125

Alqahtani, F., Khalil, M., 2019. Geochemical analysis and tectonic evaluation of the Miocene-Pliocene sequence at Al Rehaili area, Northern Jeddah, Saudi Arabia. Arab J Geosci 12, 323. https://doi.org/10.1007/s12517019-4491-0

Amajor, L.C., 1987. Major and trace elements geochemistry of Albin and Touronian shales from the Southern Benue trough, Nigeria. Journal of African Earth Science, 6, 633-641

Anthony R. West, Basic Solid State Chemistry, 2nd Edition, Wiley, London, 2001, pp. 203-210. http://tetra.simtech.a-star.edu.sg/afbsUpload/FactSheet/ICES/TA\%20Analyzer

Armstrong-Altrin, J.S., Lee, Y.I., Verma, S.P., Ramasamy, S., 2004. Geochemistry of sandstones from the Upper Miocene Kudankulam Formation, southern India: implication for provenance, weathering and tectonic setting. Journal of Sedimentary Research, 74, 285-297

Armstrong-Altrin, J.S., 2009. Provenance of sands from Cazones, Acapulco and Baha Kino beaches, Mexico. Revista Mexicana deCiencias Geologicas, 26(3), 764-782

Attwa, M. and El Shinawi, A., 2014. Geoelectrical and geotechnical investigations at tenth of Ramadan city, Egypt - A structure- Based (SB) model application. Near Surface Geoscience 2014 - 20th European Meeting of Environmental and Engineering Geophysics

B. Peng, Andrew, R. Zhaoliang, S. Changxun, Y. Xiaoyan, T. Shurong, X. Xianglin T. Tan, C., 51, 2014, 191 203.

Brookes, I. A., 2010. Spatially variable sedimentary responses to orbitally driven pluvial climate during Marine Oxygen Isotope Stage 5.1, Dakhla Oasis region, Egypt Quaternary Research, 74, 252-264.

Brooks, C.K., 1973. Rifting and doming in Southern East Greenland, Nature (London), 244, 23-24.

Campos Alvarez N.O., Roser B.P., 2007. Geochemistry of black shales from the Lower Cretaceous Paja Formation, Eastern Cordillera, Colombia: Source weathering, provenance, and tectonic setting. Journal of South American Earth Sciences 23, 271-289

Christopher Baiyegunhi, Kuiwu Liu, and Oswald Gwavava., 2017. Geochemistry of sandstones and shales from the Ecca Group, Karoo Supergroup, in the Eastern Cape Province of South Africa: Implications for provenance, weathering and tectonic setting. Geosci. 9, 340-360

Cox, R., Low, D.R., Cullers, R.L., 1995. The influence of sediment recycling and basement composition on evolution of mudrock chemistry in the southwestern United States. Geochim. Cosmochim. Acta, 59 (14), 2919-2940.

Ehlers, Ernest G. and Blat, Harvey 1982. Petrology, ligneous, Sedimentary, a Metamorphic. San Francisco: W.H freeman and company ISBN 0-716-1279-2

EL-AZABI, M.H. and EL-ARABY, A. Depositional cycles: an approach to the sequence stratigraphy of the Dakhla Formation, west Dakhla-Farafra stretch, Western Desert, Egypt. Journal of African Earth Sciences. Vol. 30. No. 4, pp. 971-996, 2000.

El-Shinawi, A and Naymushina, O.S., 2015. Geotechnical aspects of flood plain deposits in south east Aswan City, Egypt. ARPN J Eng. Appl. Sci. 10 (8), 3490-3497

Eric, R.F., 1991. Geology of titanium-mineral deposits. Special, GSA, 259, 61p.

Frederickson, A. F., 1952. Mechanism of weathering: Geological Society American, 62, 221-232. Frederickson 
Herron M.M., 1988. Geochemical classification of terrigenous sands and shales from core or log data, Journal of Sedimentary Petrology, 58, 820-829.

Jianhua Zhao, Zhijun Jin, Zhenkui Jin, Yikai Geng, XinWen, Caina Yan., 2016. Applying sedimentary geochemical proxies for paleoenvironment interpretation of organic-rich shale deposition in the Sichuan Basin, China. International Journal of Coal Geology, 163, 52-71

Keller, W.D. 1970. Environmental aspects of clay minerals, Journal of Sedimentary Petrology, 40, 788-813.

Khader, K. and McQueen, K. G., 2005. Geochemical Discrimination of Weathered bed rock in the Hermidalebyrock Region of Western NSW In: Roach I.C. Ed. Crc Leme, 170-175.

Kramarenko, V.V., El-Shinawi, A., Matveenko, I.A., Shramok, A.A., 2016. Clay swelling of Quaternary and Paleogene deposits in the south-eastern flanks of West Siberian iron ore basin. IOP Conference Series: Earth and Environmental Science, 33(1), 012041. DOI: 10.1088/1755-1315/33/1/012041

Krauskopf, K.B., 1979. Introduction to Geochemistry. New York: McGraw Hill. 721 p.

Lee, J. I., Park, B. K., Jwa, Y. J., Yoon, H. I., Yoo, K. C., Kim, Y., 2005. Geochemical characteristics and the provenance of sediments in the Bransfield Strait, West Antarctica. Mar. Geol., 219, 81-98.

Mackenzie RC ed., 1970. The smectite group, A. Dioctahedral smectites. In: Differential thermal analysis. London, Academic Press, 442-452.

McLennan, S. M. and Taylor, S. R., 1991. Sedimentary rocks and crustal evolution: Tectonic setting and secular trends. Journal of Geology, 99, 1-21.

Migdisove, A.A., 1960. On the titanium/aluminum ratios in sedimentary rocks. Geochemistry (U.S.S.R), English Transl., 2, 178-194.

Millot, G., 1970. Geology of Clays, Springer, Verlag, New York, 429p.

Mishra, M. and Sen, S., 2012, Provenance, tectonic setting and source-area weathering of Mesoproterozoic Kaimur Group, Vindhyan Supergroup, Central India. Geologica Acta, 10, 283-294.

Moufti M.R., Németh K. 2016. Geological Setting. In: Geoheritage of Volcanic Harrats in Saudi Arabia. Geoheritage, Geoparks and Geotourism (Conservation and Management Series). Springer, Cham. https://doi.org/10.1007/978-3-319-33015-0_2

Naymushina, O.S., Shvartsev, S.L., Zdvizhkov, M.A., El-Shinawi, A., 2010. Chemical characteristics of swamp waters: A case study in the Tom River basin, Russia. Water-Rock Interaction - Proceedings of the 13th International Conference on Water-Rock Interaction, WRI-13, 955-958

Nesbitt H. W. and Young G. M., 1984. Prediction of some weathering trends of plutonic and volcanic rocks based on thermodynamic and kinetic considerations. Geochimica Cosmochimica Acta, 48, 1523-1534.

Nesbitt H. W. and Young G. M., 1989.Formation and diagenesis of weathering profiles. Journal of Geology, 97 , $129-147$.

Nesbitt, H. W. and Young, G. M., 1996. Petrogenesis of sediments in the absence of chemical weathering: effects of abrasion and sorting on bulk composition and mineralogy. Sedimentology, 43, 341-358.

Nesbitt, H. W., Young, G. M., McLennan, S. M. and Keays, R. R., 1996. Effects of chemical weathering and sorting on the petrogenesis of siliciclastic sediments, with implications for provenance studies. Journal of Geology, 104, 525-542.

Nesbitt, H.W. and Young, G.M., 1982. Early Proterozoic climates and plate motions inferred from major element chemistry of lutites. Nature, 299, 715-717.

Peng, Y., Zhang, Y., Sun, J. et al., 2018. Geochemistry of Late Carboniferous sedimentary rocks from the Zongwulong structural belt and adjacent areas, Qaidam Basin, China: Implications for provenance and tectonic setting. Geosci J. 22, 287-301 https://doi.org/10.1007/s12303-017-0032-6

Pettijohn, F.J., 1975.Sedimentary Rocks. 3rd Edition, Harper and Row Publishers, 628 p.

Philippe Négrel, Anna Ladenberger, Clemens Reimann, et.al. GEMAS, 2021. Geochemical distribution of Mg in agricultural soil of Europe, Journal of Geochemical Exploration, Vol., 221, 106706, https://doi.org/10.1016/j.gexplo.2020.106706.

Ramachandran, V.S., Paroli, R.M., Beaudoin, J.J., Delgado, A.H. Handbook of thermal analysis of construction materials. No Wich, New York, Noyes Publications, William Andrew Publishing, 2002, pp. 1-5, 9-30.

Roser, B.P. and Korsch, R.J., 1988. Provenance signatures of sandstone-mudstone suites determined using discriminant function analysis of major element data. Chemical Geology, 67- 119.

Ross, D.J.K., Bustin, R.M., 2009. Investigating the use of sedimentary geochemical proxies for paleoenvironment interpretation of thermally mature organic-rich strata: examples from the DevonianMississippian shales, Western Canadian Sedimentary Basin. Chem. Geol. 260, 1-19.

Rowe, H.D., Loucks, R.G., Ruppel, S.C., Rimmer, S.M., 2008. Mississippian Barnett Formation, Fort Worth Basin, Texas: bulk geochemical inferences and Mo-TOC constraints on the severity of hydrographic restriction. Chem. Geol. 257, 16-25.

Sediek N.K., Amer M.A., 2001. Sedimentological and technological studies of Abu Tartur black shales, Western Desert, Egypt, Fizykochemiczne Problemy Mineralurgii, 35, 141-152. 
Smaill JB (2015). Geochemical variations in glauconitic minerals: applications as a potassium fertiliser resource. A thesis submitted in partial fulfillment of the requirement for the degree of Master of Science, University of Canterbury, New Zeeland, pp. 221

Song, Li-W., Sh-R., Yeh, En-Ch., Chen, Hu-F.and Jialiang, Si, 2012. Clay mineralogy and geochemistry investigations in the host rocks of the Chelungpu fault, Taiwan: Implication for faulting mechanism,Journal of Asian Earth Sciences, 59: 208-218.

Sun, G.; Wang, Y.; Guo, J.; Wang, M.; Jiang, Y.; Pan, S. Clay Minerals and Element Geochemistry of Clastic Reservoirs in the Xiaganchaigou Formation of the Lenghuqi Area, Northern Qaidam Basin, China. Minerals 2019, 9, 678. https://doi.org/10.3390/min9110678

Suttner, L.J., Dutta, P.K., 1986. Alluvial sandstone composition and palaeoclimate: I. Framework mineralogy. Journal of Sedimentary Petrology, 56, 329-345.

Tantawy, A.A., Keller, G., Adatte, T., Stinnesbeck, W., Kassab, A., and Schulte, P., 2001. Maastrichtian to Paleocene (Dakhla Formation) depositional environment of the Western Desert in Egypt: Sedimentology, Mineralogy and 21 integrated micro- and macrofossil biostratigraphies. Cretaceous Research, 22, 795827.

Thiry, M., 2000. Palaeoclimatic interpretation of clay minerals in marine deposits: an outlook from the continental origin. Earth-Science Reviews, 49: 201-221.

Turekian, K.K. and Wedepohl K.H., 1961. Distribution of the elements in some major units of the earth, s crust, Bulletin Geology Society of American, 72, 175-192.

Wanas, H.A., Abdel-Maguid, N.M., 2006. Petrography and geochemistry of the Cambro-Ordovician Wajid Sandstone, southwest Saudi Arabia: Implications for provenance and tectonic setting. J. Asian Earth Sci., $26,1-14$.

Wronkiewicz, D.J. and Condie, K.C., 1987. Geochemistry of Archean shales from the Witwatersrand Supergroup, South Africa: Source area weathering and provenance. Geochimica Cosmochimica Acta, 51, 2401-2416.

Xie, Y.; Wang, J.; Li, L.X.; Xie, Z.W.; Deng, G.H.; Li, M.H.; Jiang, X.S., 2010. Distribution of the Cretaceous clay minerals in Ordos. basin, China and its implication to sedimentary and diagenetic environment. Geol. Bull. China, 29, 93-104.

Youssef, M.I., 1957. Upper Cretaceous rocks in Kosseir area. Bulletin Institute Desert Egypt, 7, 35-54. 